\title{
COVID-19 in patients with severe asthma using biological agents
}

\author{
Kurtuluş AKSU(ID) \\ Şenay DEMIR(ID) \\ Musa TOPEL(ID) \\ Selma YEŞiLKAYA (ID) \\ Hale ATEŞ (ID) \\ illkay KOCA KALKAN(ID) \\ Ali ÖNCÜL(ID) \\ Dilek ÇUHADAR \\ ERÇELEBi(ID) \\ Süleyman \\ TÜRKYILMAZ(ID)
}

Clinic of Chest Diseases, Immunology and Allergic Diseases, Ankara Atatürk Chest Diseases and Chest Surgery Training and Research Hospital, University of Health Sciences, Ankara, Turkey Sağlık Bilimleri Üniversitesi, Ankara Atatürk Gögüs Hastalıkları ve Gögüs Cerrahisi Eğitim ve Araştırma Hastanesi, Göğüs Hastalıkları, Immünoloji ve Alerji Hastalıkları Kliniği, Ankara, Türkiye
Cite this article as: Aksu K, Demir ş, Topel M, Yeşikaya S, Atess H, Koca Kalkan i, et al. COVID-19 in patients with severe asthma using biological agents. Tuberk Toraks 2021;69(3):433-436.

\section{Address for Correspondence (Yazışma Adresi)}

\section{Dr. Kurtuluş AKSU}

Clinic of Chest Diseases, Immunology and Allergic Diseases, Ankara Atatürk Chest Diseases and Chest Surgery Training and Research Hospital, University of Health Sciences

ANKARA - TURKEY

e-mail: kurtulusaksu@yahoo.com

CCopyright 2021 by Tuberculosis and Thorax.

Available on-line at www.tuberktoraks.org.com

\section{ABSTRACT \\ COVID-19 in patients with severe asthma using biological agents}

As the COVID-19 pandemic continues, case reports have been published where patients with severe asthma using biological agents survived with a mild course of illness and encouraged the continuation of biological therapies in patients with severe asthma. However, contrary to previous information, a more severe course of COVID-19 has recently been reported in severe asthmatics using biological therapy compared to the general population.

To evaluate the COVID-19 rate and disease severity in severe asthmatics using biological agents.

A retrospective study was conducted in patients with severe asthma treated with biological agents. Data concerning whether the subjects had contracted COVID-19 and the severity of the disease were evaluated.

Eihgty-four severe asthmatics using biological agents (omalizumab or mepolizumab) aged $48.3 \pm 10.6$ years (mean \pm standard deviation) with female/male ratio: $53(63.1 \%) / 31$ (36.9\%) were included in the study. Among participants $13(15.5 \%)$ had contracted COVID-19. The course of COVID-19 was mild in five (38.5\%) and moderate in eight patients $(61.5 \%)$, while none of the patients had a severe course of COVID-19. Mechanical ventilation or intensive care follow-up was not required in any of the six patients $(46.2 \%)$ who were treated as inpatients. All participants survived COVID-19 in full recovery and no deaths occurred in the cases.

A higher rate of COVID-19 was found in patients with severe asthma using biologics compared to those reported in previous reports. However, all patients with COVID-19 have a mild to moderate disease course.

Key words: Severe asthma; omalizumab; mepolizumab; COVID-19 


\section{ÖZ}

\section{Biyolojik ajan kullanan ağır astımlı hastalarda COVID-19}

COVID-19 pandemisi devam ederken, biyolojik ajan kullanan ağır astımlı hastaların hafif bir hastalık seyri gösterdiği ve ağır astımı olan hastalarda biyolojik tedavilerin devamını teşvik eden vaka raporları yayınlanmıştır. Bununla birlikte önceki bilgilerin aksine, son zamanlarda biyolojik tedavi kullanan şiddetli astımlılarda genel popülasyona kıyasla daha şiddetli bir COVID-19 seyri de bildirilmiştir. Bu çalışmada biyolojik ajan kullanan ağır astımılıarda COVID-19 oranını ve hastalık şiddetini değerlendirmek amaçlanmıştır.

Biyolojik ajanlarla tedavi edilen ağır astımlı hastalarda retrospektif bir çalışma yapılmıştır. Deneklerin COVID-19'a yakalanıp yakalanmadığına ve hastalı̆̆ın ciddiyetine ilişkin veriler değerlendirilmiştir.

Biyolojik ajan kullanan (omalizumab veya mepolizumab) yaşları 48,3 \pm 10,6 (ortalama \pm standart sapma) olan, kadın/erkek oranı: $53(\% 63,1) / 31(\% 36,9)$ olan 74 ağır astımlı çalışmaya dahil edildi. Katılımcıların 13’ü $(\% 15,5)$ COVID-19'a yakalanmıştı. COVID19 'un seyri beş hastada $(\% 38,5)$ hafif, sekiz hastada $(\% 61,5)$ ortaydı; hiçbir hastada ciddi bir COVID-19 seyri görülmedi. Yatarak tedavi edilen altı hastanın hiçbirinde $(\% 46,2)$ mekanik ventilasyon veya yoğun bakım takibi gerekmedi. Tüm katılımcılar COVID-19'u tamamen iyileşerek atlattı ve vakalarda ölüm meydana gelmedi.

Önceki raporlarda bildirilenlere kıyasla biyolojik tedavi kullanan ağır astımlı hastalarda daha yüksek bir COVID-19 oranı bulundu. Bununla birlikte, COVID-19'lu tüm hastalar hafif ila orta derecede hastalık seyrine sahipti.

Anahtar kelimeler: Ağır astım; omalizumab; mepolizumab; COVID-19

To the Editor,

Information on the severity of COVID-19 in patients with severe asthma using biological agents is limited. There is no evidence that blocking type 2 inflammation with the IL4 R-[alpha] antagonist, anti-IgE, and anti-IL5 agents increases the risk of SARS-CoV-2 infection (1). The severity of COVID-19 in asthmatic patients likely depends on some factors. The use of maintenance therapy with inhaled corticosteroids in patients with asthma and well-controlled disease are likely to pose a low risk for COVID-19 (2). Eosinophil depletion caused by anti-IL 5 and anti-IL 5 receptor blocking monoclonal antibodies is another concern as to whether it would create an increased risk for severe COVID-19 (3). Luckily, the good news is that, case reports encourage the continuation of biological therapies in patients with severe asthma during the COVID-19 pandemic $(4,5)$. However, contrary to reports that severe asthmatic patients using biological agents survived COVID-19 with a mild disease course, a recent study in the Netherlands has reported a more severe course of COVID-19 in these patients compared to the general population (6). Therefore, there is still a need for concrete data on this subject.

The rate of COVID-19 and disease severity in adults with severe asthma using biological agents was evaluated in a retrospective study conducted in an allergy clinic in a tertiary chest diseases hospital between November 2020 and January 2021. All subjects followed up in the clinic with a diagnosis of severe asthma and treated with biologics and who agreed to participate in the study were included. The study was approved by Ankara Keçiören Educational Research Hospital Clinical Research Ethics Committee (November 11, 2020/2191). The subjects were questioned whether they had contracted COVID-19 since the beginning of the pandemic, the course of COVID19 , and their hospitalization history.

Eighty-four subjects were included in the study. Patients' mean age was 48.3 years (standard deviation 10.6 years), and sex distribution was 53 females $(63.1 \%)$ and 31 males $(36.9 \%)$. There were nine $(10.7 \%)$ current smokers. Thirty-one (36.9\%) subjects were obese (body-mass index; $\mathrm{BMI} \geq 30 \mathrm{~kg} / \mathrm{m}^{2}$ ) and two $(2.4 \%)$ were morbidly obese (BMl> $\left.40 \mathrm{~kg} / \mathrm{m}^{2}\right)$. All patients were using inhaled corticosteroids, long-acting $\beta-2$ agonists, and one of two biologic agents approved for use in severe asthma in the country; omalizumab $(n=62)$ and mepolizumab $(n=22)$. Fourteen $(16.7 \%)$ of the cases had allergic rhinitis, four $(4.8 \%)$ had chronic urticaria, six $(7.1 \%)$ had hypertension, and six (7.1\%) had diabetes mellitus as co-morbid diseases.

Thirteen subjects (15.5\%) had contracted COVID-19 disease, 11 of whom had a positive SARS-CoV-2 PCR test in nasopharyngeal swab samples, and two had symptoms suggestive of COVID-19 together with radiological findings consistent with COVID-19. Of the 13 patients diagnosed with COVID-19, 12 $(92.3 \%)$ had fatigue, eight $(61.5 \%)$ fever, eight $(61.5 \%)$ cough, seven $(53.8 \%)$ dyspnea, three $(23.1 \%)$ had diarrhea and two (15.4\%) anosmia. The severity of the disease was mild in five patients (38.5\%), moderate in eight patients $(61.5 \%)$, while none of them had a severe course of COVID-19. Seven patients 
$(53.8 \%)$ were treated as outpatients, six $(46.2 \%)$ inpatients, none required mechanical ventilation or intensive care follow-up, and all survived with full-recovery. The demographic and clinical parameters such as age, gender distribution, body-mass index, comorbid diseases and allergic conditions were not significantly different between severe asthmatics had and had not contracted COVID-19 (Table 1).

One of the five patients (20\%) who had mild COVID19 and four $(50 \%)$ of the eight patients who had moderate COVID-19 were male. Diabetes was present in one $(20 \%)$ of patients with mild COVID-19 and one $(12.5 \%)$ of patients with moderate severity. While hypertension and obesity were not observed in patients with mild COVID-19, two (25\%) of the patients with moderate severity had hypertension and four (50\%) had obesity. Biological agent distribution (omalizumab/mepolizumab) was three $(60 \%) / 2$ $(40 \%)$ in patients with mild COVID-19, while it was $6(75 \%) / 2(25 \%)$ in patients with moderate severity. Statistical analysis was not performed on these data due to the small number of cases.

In our study, the rate of COVID-19 was found 6 to 10 times higher in patients with severe asthma using biological agents compared to the rates reported in previous studies $(6,7)$. A reason for this might be that SARS-CoV-2 PCR testing is done to every individual with any of the symptoms of COVID-19 in our country. Another possible reason may be that asthmatic patients on biologics have an increased risk of contracting SARS-CoV-2 due to their regular hospital admission. The most striking result of our study is that none of the patients had a severe course of COVID19 or required mechanical ventilation or intensive care follow-up. This finding is consistent with the previous case reports and the findings in the study of Hanon et al., which investigated the risk and severity of COVID-19 in a cohort of patients with severe asthma $(4,5,7)$. The contradictory findings reported by Eger et al. revealing patients with severe asthmatics on biologics have a more severe course of COVID-19 compared to the general population is really interesting and need to be discussed (6). In that report nine of 634 severe asthma patients who received biological therapy in the RAPSODI cohort had COVID-19. Seven of these patients were hospitalized for oxygen therapy, even five were admitted to intensive care for intubation and mechanical ventilation and one died. When the characteristics of the patients with COVID19 in that cohort are examined, it is seen that those with severe disease have at least one comorbidity, mainly obesity. In addition, these patients are older than the patients included in our study. Despite our limited knowledge about the risk factors of COVID19, advanced age, obesity, and comorbidities, especially hypertension and cardiac diseases are the parameters that are clearly related to the severity of COVID-19 $(3,8)$. The lower mean age, body mass index and frequency of comorbidity of the patients in our study is the most likely reason why our findings regarding the severity of COVID-19 in patients were contrary to Eger et al (6). In the very recent editorial, Eger and Bel concluded in the light of studies pub-

Table 1. Demographic, clinical, and smoke-related characteristics of subjects with and without COVID-19 $(n=84)$

\begin{tabular}{|c|c|c|c|}
\hline & COVID-19 $(n=13)$ & No-COVID-19 $(n=71)$ & $\mathbf{p}$ \\
\hline Age (years); mean (SD) & $48.9(8.2)$ & $48.2(11.0)$ & 0.834 \\
\hline Gender (Male/Female) & $5(38.5) / 8(61.5)$ & $26(36.6) / 45(63.4)$ & 1.000 \\
\hline Obesity (Body-mass index> $30 \mathrm{~kg} / \mathrm{m}^{2}$ ) & $4(30.8)^{¥}$ & $27(38.0)^{\delta}$ & 0.759 \\
\hline Diabetes mellitus & $2(15.4)$ & $4(5.6)$ & 0.231 \\
\hline Hypertension & $2(15.4)$ & $4(5.6)$ & 0.231 \\
\hline Allergic rhinitis & 0 & $14(19.7)$ & 0.113 \\
\hline Chronic urticaria & $1(7.7)$ & $3(4.2)$ & 0.496 \\
\hline Current smokers & 0 & $9(12.7)$ & 0.343 \\
\hline Biological agent (Omalizumab/Mepolizumab) & $9(69.2) / 4(30.8)$ & $53(74.6) / 18(25.4)$ & 0.735 \\
\hline Duration of treatment with biologicals (months); mean (SD) & $35.7(27.1)$ & $39.9(33.3)$ & 0.701 \\
\hline \multicolumn{4}{|c|}{$\begin{array}{l}\text { Data are indicated in } \mathrm{n}(\%) \text { unless otherwise stated. SD: Standard deviation. } \\
¥ \text { One patient had body-mass index }>40 \mathrm{~kg} / \mathrm{m}^{2} \text {. } \\
{ }^{\delta} \text { Two patients had body-mass index> } 40 \mathrm{~kg} / \mathrm{m}^{2} \text {. }\end{array}$} \\
\hline
\end{tabular}


lished so far, asthma patients appear somewhat more susceptible to contracting COVID-19, but severe disease progression does not appear to be associated with drug use, including asthma biologics, yet seems to be associated with more advanced age and comorbidities (9).

In conclusion, among the patients with severe asthma using biologics, rate of COVID-19 is quite higher compared to the COVID-19 rates in the previous reports. However, all patients with COVID-19 had mild to moderate disease course, and no patients died revealing that COVID-19 does not pose an additional risk in patients using with severe asthma using biological therapy. It is clear that understanding the relationship between the pathogenesis of severe asthma and the mechanisms of action of biological agents and COVID-19 will have important implications for the evaluation and follow-up of these patients.

\section{REFERENCES}

1. Assaf SM, Tarasevych SP, Diamant Z, Hanania NA. Asthma and severe acute respiratory syndrome coronavirus 2019: current evidence and knowledge gaps. Curr Opin Pulm Med 2021; 27(1): 45-53.
2. Maes T, Bracke K, Brusselle GG. Reply to Lipworth et al. Inhaled Corticosteroids and COVID-19. Am J Respir Crit Care Med 2020; 202(6): 900-2.

3. Jesenak M, Banovcin P, Diamant Z. COVID-19, chronic inflammatory respiratory diseases and eosinophils-Observations from reported clinical case series. Allergy 2020; 75(7): 1819-22

4. Lommatzsch $M$, Stoll P, Virchow JC. COVID-19 in a patient with severe asthma treated with omalizumab. Allergy 2020; 75: 2705-8.

5. Aksu K, Yesilkaya S, Topel M. COVID-19 in a patient with severe asthma using mepolizumab. Allergy Asthma Proc 2021; 42(2): e55-e57.

6. Eger K, Hashimoto S, Braunstahl GJ. Poor outcome of SARS-CoV-2 infection in patients with severe asthma on biologic therapy. Respir Med 2020; 177: 106287.

7. Hanon S, Brusselle G, Deschampheleire M. COVID-19 and biologics in severe asthma: data from the Belgian Severe Asthma Registry. Eur Respir J 2020; 56(6): 2002857.

8. Du RH, Liang $L R$, Yang CQ. Predictors of mortality for patients with COVID-19 pneumonia caused by SARSCoV-2: a prospective cohort study. Eur Respir J 2020; 55(5): 2000524.

9. Eger K, Bel EH. Asthma and COVID-19: do we finally have answers? Eur Respir J 2021; 57(3): 2004451. 